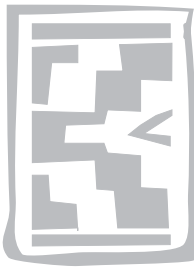

\title{
Comparison of three different media for freezing of epididymal sperm from the African buffalo (Syncerus caffer) and influence of equilibration time on the post-thaw sperm quality
}

\author{
F.C. HEROLD ${ }^{1}$, K. DE HAAS ${ }^{1}$, D. COOPER ${ }^{2}$, B. COLENBRANDER ${ }^{3}$, J.O. NÖTHLING ${ }^{1}$, \\ W. THEUNISEN ${ }^{4}$, B. SPILLINGS ${ }^{4}$ and D. GERBER ${ }^{1}$
}

\begin{abstract}
HEROLD, F.C., DE HAAS, K., COOPER, D., COLENBRANDER, B., NÖTHLING, J.O., THEUNISEN, W., SPILLINGS, B. \& GERBER, D. 2004. Comparison of three different media for freezing of epididymal sperm from the African buffalo (Syncerus caffer) and influence of equilibration time on the post-thaw sperm quality. Onderstepoort Journal of Veterinary Research, 71:203-210

Assisted reproductive techniques might prove themselves useful tools in producing buffaloes free of specific diseases (BFSD), which are in demand in South Africa. Freezing protocols for African buffalo semen must not only result in good post-thaw qualities, but must also be practical. Epididymal sperm from six mature African buffalo bulls was collected, diluted with three different semen extenders and frozen. Pre-freezing equilibration times between 2 and $9 \mathrm{~h}$ were tested. Total and progressive motility, longevity and acrosomal integrity were measured and compared. The use of Trilady $\mathrm{I}^{\mathrm{TM}}$ proved to result in better post-thaw parameters than the other two diluents. Equilibration times of between 4 and $9 \mathrm{~h}$ did not influence post-thaw sperm qualities significantly. For some of the treatments, exposure to semen extenders before freezing for less than $4 \mathrm{~h}$ resulted in inferior postthaw semen parameters.
\end{abstract}

Keywords: African buffalo, AndroMed®, epididymal, Red Ovine Freezing Buffer, sperm, Syncerus caffer, Triladyl ${ }^{\mathrm{TM}}$

\section{INTRODUCTION}

After the outbreak of rinderpest at the turn of the $19^{\text {th }}$ century the bulk of the African buffalo (Syncerus caffer) population was restricted to the Kruger National Park, the Hluhluwe and Umfolozi Nature Reserves and the Addo Elephant National Park. Since the Addo population was the only one free

1 Section of Reproduction, Department of Production Animal Studies, Faculty of Veterinary Science, University of Pretoria, Private Bag X04, Onderstepoort, 0110 South Africa

2 KZN Nature Conservation Service, Private Bag X01, St. Lucia, 3936 South Africa

3 Department of Farm Animal Health, Section of Reproduction, Faculty of Veterinary Medicine, Utrecht University, Yalelaan 12, 3854 CM Utrecht, The Netherlands

4 Wildlife Biological Resource Centre, Endangered Wildlife Trust, P.O. Box 582, Pretoria, 0001 South Africa

Accepted for publication 9 March 2004-Editor from foot-and-mouth disease (FMD) and Corridor disease (CD) most of the animals outside the three areas mentioned derive from them (De Vos 1987).

African buffaloes are considered long-term carriers of the three SAT types of the FMD virus (Hedger \& Condy 1985; Bengis, Thomson \& De Vos 1987) as well as of Theileria parva lawrencei, the causative agent of CD (Potgieter, Stoltsz, Blouin \& Roos 1988). Furthermore, they are considered a source of re-infection of domestic cattle for bovine tuberculosis (Bengis, Kriek, Keet, Raath, De Vos \& Huchzermeyer 1996) and brucellosis (Herr \& Marshall 1981). Transporting African buffaloes in South Africa is therefore subject to strict regulations.

Different approaches to satisfy the demand for buffaloes free of specific diseases (BFSD) among private game farmers, to increase the genetic variety outside the endemic areas and to reap the existing 
benefits of larger trophy sizes of animals from the Kruger National Park, have been adopted (Gerber 2000). Special breeding programmes are one and, in future, assisted reproductive techniques might become another.

Attempts to freeze epididymal sperm from African buffaloes have been made in the past (Bartels, Lambrechts, Kidson \& Friedmann 1996; Lambrechts, Van Niekerk, Coetzer, Cloete \& Van der Horst 1999; Kilian, Lubbe, Bartels, Friedmann \& Denniston 2000; Gerber, Irons, Arlotto \& Cooper 2001; Gerber, Irons, Herold \& Cooper 2002; Lubbe, Bartels, Kilian, Friedman \& Mortimer, unpublished data 2000) and total post-thaw motility varied from $19 \%$ to $45 \%$.

Semen diluents used in all previous trials contained egg yolk. The presence of hormones (Hartmann, Lacorn \& Steinhardt 1998) in them as well as problems arising from lack of hygiene may affect the fertilizing capacity of spermatozoa (Müller-Schlösser, Aires, Hinsch \& Hinsch 2001).

Since collection of sperm from the African buffalo is often done in the field, ideal conditions are not necessarily present. A useful freezing method must therefore not only result in high post-thaw qualities but must also be practical. The aim of this study was to evaluate the influence of equilibration time of different semen extenders on post-thaw sperm qualities such as motility, longevity and acrosomal integrity, parameters that are routinely used for semen evaluation (Stewart \& O'Hagan 1972; Correa \& Zavos 1995; Garner, Thomas \& Gravance 1999).

The study was also designed to evaluate the suitability of an egg yolk-free semen diluent (AndroMed®, Minitüb, Germany) and to compare it to two egg yolkcontaining media (Trilady| ${ }^{\mathrm{TM}}$, Minitüb, Germany and Red Ovine Freezing Buffer, IMV, France).

\section{MATERIALS AND METHODS}

Epididymides were collected from six African buffalo bulls culled during a disease eradication programme in Huhluwe/Umfolozi National Park in September 2001. This programme was performed under the responsibility of the KwaZulu-Natal Nature Conservation Service. All animals were killed by means of rifle shot and only bulls which had three or more pairs of permanent lower incisors (about 3-3.5 years of age) were used in the trial.

The testes and epididymides from each bull were collected through a scrotal incision within $10 \mathrm{~min}$ after culling. An effort was made to remove as much as possible of the vas deferens. The vas deferens, the tail of the epididymis and part of the body were dissected free from the testis. The epididymal duct was then dissected free and transected on the site in the tail of the epididymis where the tubular diameter becomes distinctly larger distally. A blunted 23 or $25 \mathrm{G}$ hypodermic needle connected to a $10 \mathrm{~m} \ell$ syringe was then inserted into the lumen of the vas deferens and the sperm was flushed with air in a retrograde direction from the tail of the epididymis and collected in a sterile plastic tube. All epididymides were flushed within 30 min of death of the animal.

The harvested sperm of both epididymides of the same bull were mixed and split into three aliquots, each of which was poured into a $15 \mathrm{~m} \ell$ plastic tube, containing $13 \mathrm{~m} \ell$ of one of the three different cryodiluents. The three semen extenders used were Trilady| ${ }^{\mathrm{TM}}$, AndroMed( ${ }^{\circledR}$ (both Minitube, Germany) and Red Ovine Freezing Buffer (IMV, France). The glycerol concentrations of these media are $6.6 \%$, $6.8 \%$ and $3.5 \%$, respectively. The concentration of the sperm/diluent mixture was determined with a haemocytometer and was between 100 and $150 \mathrm{x}$ $10^{6}$ sperm cells per $\mathrm{m} \ell$.

The sperm-diluent suspension was mixed and the three $15 \mathrm{~m} \ell$ tubes were placed in a $500 \mathrm{~m} \ell$ water bottle containing water at a temperature of $20^{\circ} \mathrm{C}$. The water bottle was placed into a Styrofoam box containing water and ice cubes in such a relationship that the temperature of the water was $4^{\circ} \mathrm{C}$ resulting in a cooling rate of $0.25^{\circ} \mathrm{C} / \mathrm{min}$. The samples were then transported to a laboratory.

\section{Evaluation of fresh semen}

Before further processing the total and progressive sperm motility from each solution was evaluated by means of eyeball assessment using a phase contrast microscope. Percentages of progressive and total motile sperm cells were recorded.

\section{Freezing of semen}

After $2 \mathrm{~h}$ five $0.25 \mathrm{~m} \ell$ French straws were loaded from each of the three sperm dilutions, dried and placed $4 \mathrm{~cm}$ above liquid nitrogen for $10 \mathrm{~min}$ before being plunged into and stored in a nitrogen tank until thawing. The $15 \mathrm{~m} \ell$ tubes containing the remaining sperm dilutions were further kept in water bottles in a water bath at $4{ }^{\circ} \mathrm{C}$. The procedure of packing and freezing straws was repeated eight times every hour. 


\section{Thawing of semen}

After a storage time of between 4 and 37 days the straws were thawed in a water bath at a temperature of $37^{\circ} \mathrm{C}$ for at least $30 \mathrm{~s}$. The contents of two straws of the same treatment were emptied into two different pre-heated $\left(37^{\circ} \mathrm{C}\right) 3 \mathrm{~m} \ell$ Perspex tubes and stored in a water-bath at $37^{\circ} \mathrm{C}$.

\section{Evaluation of the post-thaw semen quality}

\section{Motility}

An amount of $25 \mu \ell$ of the thawed semen were further diluted with $100 \mu \ell$ of the corresponding diluent to determine the total and progressive sperm motility. The motility of the semen from both thawed straws was determined by eyeball assessment using a phase contrast microscope. In the rare event of remarkable differences this was attributed to handling, and the percentage of total and progressive motile sperm cells of the sample, which had a higher motility, was recorded.

\section{Longevity}

The longevity of the sperm was assessed by evaluating the total and progressive motility of the equilibrated sperm immediately (0), 1 and $2 \mathrm{~h}$ after thawing. During this time the sperm samples were kept in a water bath at $37^{\circ} \mathrm{C}$.

\section{Acrosomal integrity}

The acrosomal integrity was evaluated after a storage time of 5 months. The content of a thawed $0.25 \mathrm{~m} \ell$ straw was then emptied into an Eppendorf tube. The semen diluent mixture was washed twice with $200 \mu \ell$ of PBS by centrifugation at $600 \mathrm{~g}$ for 5 min. The supernatant was removed and the pellet re-suspended with $200 \mu \ell$ of PBS. Fifty microlitres of IGEPAL CA-630 (Sigma-Aldrich Ltd, Atlasville, South Africa, cat no: D1626) and $50 \mu \ell$ of EthD-1 (Ethidium Homodimer, Laboratory Specialist Services Ltd, Clareich, South Africa, cat no: E-1149) were added and the suspension incubated for $5 \mathrm{~min}$ at $37^{\circ} \mathrm{C}$. IGEPAL CA-630 was added to permeabilize the sperm membrane and EthD-1 to stain the DNA red. Then $5 \mu \ell$ of $1 \mathrm{mg} / \mathrm{m} \ell$ ssDNA (deoxyribonucleic acid sodium from Salmon, Sigma-Aldrich Ltd, Atlasville, South Africa, cat no: D1626) were added to bind the free EthD-1 and it was further incubated for 1-2 min. Spermatozoa were fixed by addition of $50 \mu \ell$ of $4 \%$ paraformaldehyde and $1 \%$ glutaraldehyde in PBS and kept in the dark for $1 \mathrm{~min}$ before being washed once with $200 \mu \ell$ of PBS by centrifugation at $600 \mathrm{~g}$ for $5 \mathrm{~min}$. The supernatant was removed and the pellet re-suspended with $50 \mu \ell$ of PBS. Fifty microlitres of FITC-PNA (Lectin from Arachis Hypogaea*Fluorescein, Sigma-Aldrich Ltd, Atlasville, South Africa, cat no: L7381) were added and the suspension was incubated for $10 \mathrm{~min}$ at $37^{\circ} \mathrm{C}$. It was again washed once with $200 \mu \ell$ of PBS by centrifugation at $600 \mathrm{~g}$ for $5 \mathrm{~min}$, the supernatant was removed, re-suspended with $25-100 \mu \ell$ of PBS and kept in the dark. Equal amounts of $2 \mu \ell$ sperm suspension and of antifade (Slowfade Antifade Kit, Laboratory Specialist Services Ltd, Clareich, South Africa, cat no: S-2828) were placed on a microscopic slide and covered with a cover slip. The edges of the coverslip were sealed with nail polish to prevent drying out. The samples were examined under an epifluorescence microscope (BH2-RFCA; Olympus, Tokyo, Japan) at a magnification of 400-1000.

Spermatozoa were classified according to their appearance as acrosome intact, acrosome damaged or devoid of acrosome (Fig. 1). One hundred spermatozoa of each sample were evaluated and the results expressed as percentages.

\section{Statistical analysis}

\section{ANOVA}

A "Repeated Measure One Way ANOVA" was used to test for differences between the eight different equilibration times separately for the use of AndroMed®, Trilady ${ }^{\mathrm{TM}}$ or Red Ovine Freezing Buffer. The same test was used to compare the different media. To identify different groups the Tukey test was used. In the event that normality failed, the Friedman repeated measures ANOVA on ranks was used. Total and progressive motility were compared separately at every measurement.

\section{Longevity}

After it became evident that equilibration times between 4 and $9 \mathrm{~h}$ did not yield different results, the mean values for these equilibration times were used for each buffalo and motilities before freezing, immediately, $1 \mathrm{~h}$ and $2 \mathrm{~h}$ after thawing were compared with each other by means of a "Repeated Measure One Way ANOVA". To identify different groups the Tukey test was used.

\section{RESULTS}

Total and progressive motilities of fresh sperm samples varied between the bulls and averaged $57 \pm$ 
Freezing of epididymal sperm from African buffalo (Syncerus caffer)

TABLE 1 Comparison of total and progressive motilities (\%) \pm SD of all three media. Each value represents the mean of equilibration times of 4-9 h. Values with different superscripts within columns differ significantly. Measurements were taken before freezing (fresh), immediately $(0 \mathrm{~h}), 1 \mathrm{~h}$ and $2 \mathrm{~h}$ after thawing. ROFB $=$ Red Ovine Freezing Buffer

\begin{tabular}{|c|c|c|c|c|c|c|c|c|}
\hline Medium & $\begin{array}{l}\text { Fresh - } \\
\text { total }\end{array}$ & $\begin{array}{l}\text { Fresh - } \\
\text { progessive }\end{array}$ & $\begin{array}{l}0 \mathrm{~h}- \\
\text { total }\end{array}$ & $\begin{array}{l}0 \mathrm{~h}- \\
\text { progressive }\end{array}$ & $\begin{array}{l}1 \mathrm{~h}- \\
\text { total }\end{array}$ & $\begin{array}{l}1 \mathrm{~h}- \\
\text { progressive }\end{array}$ & $\begin{array}{l}2 \mathrm{~h}- \\
\text { total }\end{array}$ & $\begin{array}{l}2 \mathrm{~h}- \\
\text { progressive }\end{array}$ \\
\hline AndroMed® & $57 \pm 17$ & $31 \pm 21$ & $46 \pm 13^{a}$ & $14 \pm 14^{a}$ & $48 \pm 12^{a}$ & $7 \pm 11^{a}$ & $45 \pm 12^{a}$ & $3 \pm 6^{a}$ \\
\hline Trilady $^{\mathrm{TM}}$ & $56 \pm 13$ & $19 \pm 11$ & $54 \pm 13^{a, b}$ & $19 \pm 12^{a}$ & $56 \pm 13^{a, b}$ & $21 \pm 15^{b}$ & $49 \pm 12^{a}$ & $16 \pm 11^{b}$ \\
\hline ROFB & $58 \pm 14$ & $24 \pm 15$ & $57 \pm 12^{b}$ & $29 \pm 15^{b}$ & $58 \pm 15^{b}$ & $10 \pm 13^{a}$ & $51 \pm 16^{a}$ & $2 \pm 6^{a}$ \\
\hline
\end{tabular}

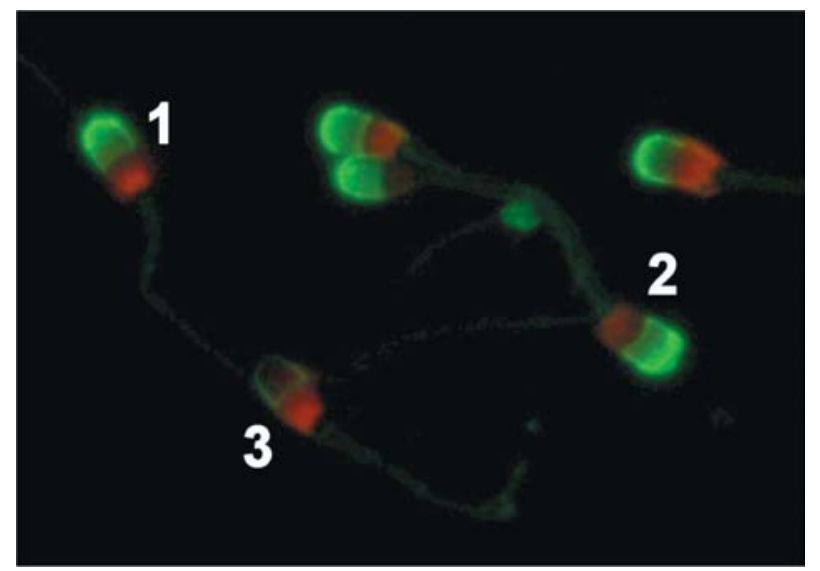

FIG. 1 Spermatozoa from the African buffalo after freezing and thawing, stained with FITC-PNA

$1=$ sperm cell with intact acrosome, $2=$ sperm cell with damaged or reacting acrosome and $3=$ sperm cell with reacted or lost acrosome

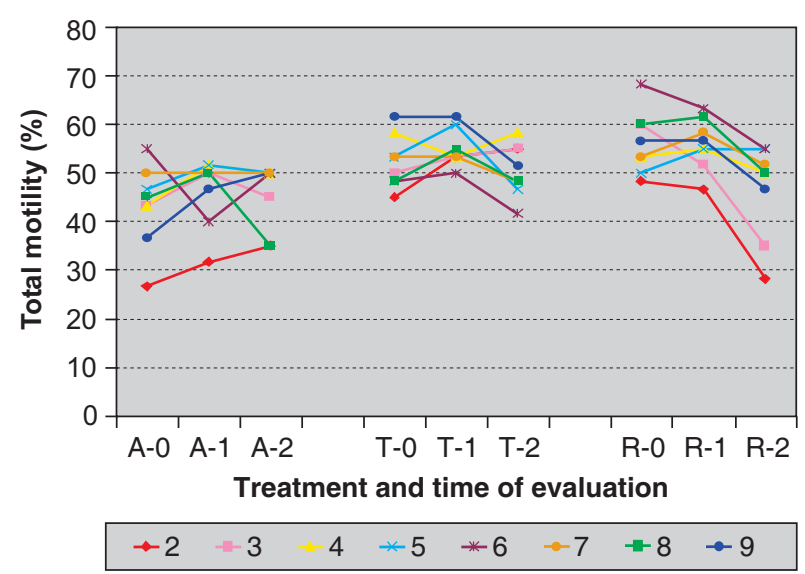

FIG. 2 Comparison of total sperm motility (\%) in respect of different pre-freezing equilibration times $(2-9$ h) and longevity for sperm frozen in the diluents AndroMed ${ }^{\circledR}$, Triladyl ${ }^{\mathrm{TM}}$ and Red Ovine Freezing Buffer (ROFB)

All values are means of the six bulls. $A=$ AndroMed ${ }^{A}$, $\mathrm{T}=$ Trilady $^{\mathrm{TM}} \mathrm{M}$ and $\mathrm{R}=$ Red Ovine Freezing Buffer. Motilities were evaluated immediately $(0 \mathrm{~h}), 1 \mathrm{~h}$ and 2 $\mathrm{h}$ after thawing

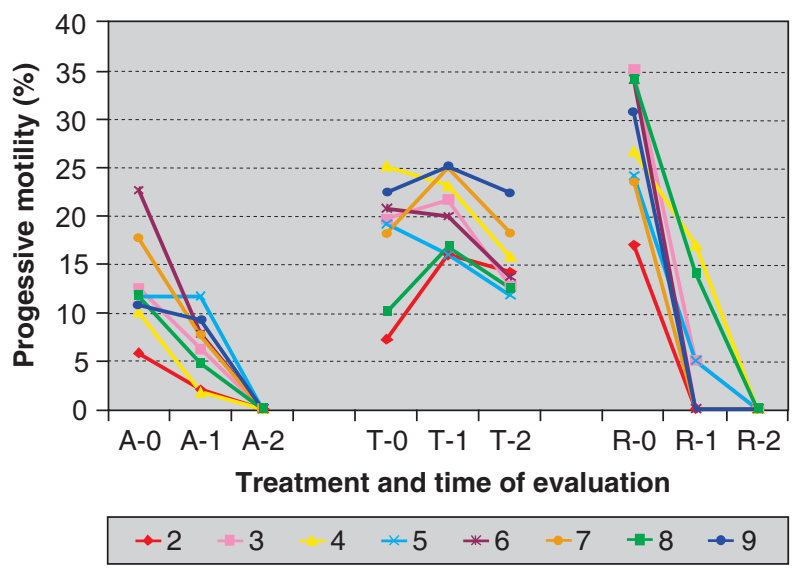

FIG. 3 Comparison of progressive sperm motility (\%) in respect of different equilibration times (2-9 h) and longevity for sperm frozen in the diluents AndroMed®, Trilady $\mathrm{I}^{\mathrm{TM}}$ and Red Ovine Freezing Buffer (ROFB)

All values are means of the six bulls. $A=$ AndroMed ${ }^{\circledR}$, $\mathrm{T}=$ Trilady $\mathrm{T}^{\mathrm{T} M}$ and $\mathrm{R}=$ Red Ovine Freezing Buffer. Motilities were evaluated immediately $(0 \mathrm{~h}), 1 \mathrm{~h}$ and 2 $\mathrm{h}$ after thawing

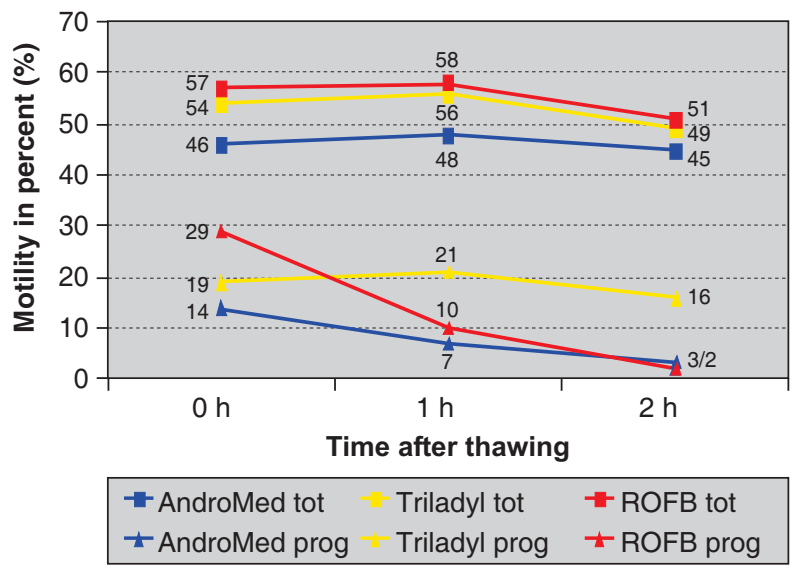

FIG. 4 Comparison of longevity for sperm frozen in the diluents AndroMed $\AA$, Triladyl ${ }^{\mathrm{TM}}$ and Red Ovine Freezing Buffer (ROFB)

Each value represents the mean of equilibration times between 4 and $9 \mathrm{~h}$. Measurements were taken immediately $(0 \mathrm{~h}), 1 \mathrm{~h}$ and $2 \mathrm{~h}$ after thawing for total (tot) and progressive (prog) motility 
$19 \%$ (mean $\pm S D$, range $33-80 \%$ ) and $31 \pm 23 \%$ (range 10-60\%), respectively.

Post-thaw total motility $(t=0)$ of sperm frozen with AndroMed $\AA$, Trilady $\mathrm{I}^{\mathrm{TM}}$ or Red Ovine Freezing Buffer was $43 \pm 15 \%, 52 \pm 14 \%$, and $56 \pm 13 \%$, respectively. Equilibration time significantly affected post-thaw motility. Short equilibration times (2 and $3 \mathrm{~h})$ negatively affected post-thaw sperm motility, being $27 \pm 19 \%$ and $43 \pm 12 \%, 45 \pm 10 \%$ and 50 $\pm 20 \%$ as well as $48 \pm 10 \%$ and $60 \pm 20 \%$ for AndroMed®, Trilady| ${ }^{\mathrm{TM}}$ and Red Ovine Freezing Buffer, respectively (Fig. 2). Equilibration periods over $3 \mathrm{~h}$ resulted in significantly higher motility percentages, being $46 \pm 13 \%, 54 \pm 13 \%$ and $57 \pm 12 \%$ for AndroMed $\AA$, Triladyl ${ }^{\mathrm{TM}}$ and Red Ovine Freezing Buffer, respectively. No differences were observed between the longer (4-9 h) incubation periods. Total motility did not significantly decline within $2 \mathrm{~h}$ after thawing, apart for samples frozen with Red Ovine Freezing Buffer (Table 1 and Fig. 4).

Post-thaw progressive motility $(t=0)$ of sperm frozen with AndroMed $\AA$, Trilady $\left.\right|^{\mathrm{TM}}$ or Red Ovine Freezing Buffer was $13 \pm 13 \%, 18 \pm 12 \%$ and $28 \pm$ $16 \%$, respectively. Equilibration time significantly affected post-thaw motility. Short equilibration times ( 2 and $3 \mathrm{~h}$ ) negatively effected post-thaw sperm motility being $6 \pm 9 \%$ and $12 \pm 14 \%, 7 \pm 7 \%$ and $20 \pm 13 \%$ as well as $17 \pm 17 \%$ and $35 \pm 20 \%$ for AndroMed $\AA$, Trilady| ${ }^{\mathrm{TM}}$ and Red Ovine Freezing Buffer, respectively (Fig. 3). Equilibration periods over $3 \mathrm{~h}$ resulted in significantly higher motility percentages, being $14 \pm 14 \%, 19 \pm 12 \%$ and $29 \pm$ $15 \%$ for AndroMed $\AA$, Trilady| ${ }^{\mathrm{TM}}$ and Red Ovine Freezing Buffer, respectively. No differences were observed between the longer (4-9 h) incubation periods. Progressive motility did significantly decline within $2 \mathrm{~h}$ after thawing to almost 0 in samples frozen with AndroMed $\AA$ and Red Ovine Freezing Buffer (3 $\pm 6 \%$ and $2 \pm 6 \%$, respectively) but did not decline in samples frozen with TriladylTM (Fig. 4).

When acrosomal integrity was evaluated AndroMed proved to be inferior to both other media. The percentage of intact acrosomes did not differ within diluents or equilibration times. The acrosomal integrity was therefore analysed again to test for differences between the diluents when all the equilibration times were pooled. Trilady $\mathrm{I}^{\mathrm{TM}}$ resulted in $56 \pm 7 \%$ intact acrosomes, which is significantly higher than the results for AndroMed $\AA$ ( $52 \pm 7 \%)$. ROFB (55 \pm $6 \%)$ did not differ from the other two extenders.

When the percentages of lost acrosomes were compared, an equilibration time of $2 \mathrm{~h}$ resulted in significantly lower percentages than when equili-

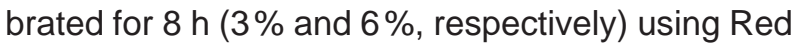
Ovine Freezing Buffer.

Furthermore, the use of AndroMed( $\AA$ resulted in significantly higher percentages (6\%) of lost acrosomes than both other media (4\% and $3 \%$ for Triladyl ${ }^{\mathrm{TM}}$ and ROFB, respectively), when equilibrated for $2 \mathrm{~h}$. AndroMed also yielded significantly higher numbers of lost acrosomes compared to Red Ovine Freezing Buffer after an equilibration time of $5 \mathrm{~h}(8 \%$ and $4 \%$, respectively) and compared to Trilady| ${ }^{\mathrm{TM}}$ when equilibrated for $8 \mathrm{~h}(7 \%$ and $3 \%$, respectively).

\section{DISCUSSION}

Epididymal sperm from the African buffalo can successfully be frozen-thawed in Trilady $\mathrm{I}^{\mathrm{TM}}$ extender when adequate equilibration times are applied. Owing to the deleterious effects of tissue degeneration it is recommended that spermatozoa be recovered immediately post-mortem (Hopkins, Armstrong, Hummel \& Junior 1988). Therefore, we decided to flush epididymal sperm as soon after culling as possible (in our case this was $30 \mathrm{~min}$ ) and keep the samples in semen diluents rather than transport the whole epididymides as such.

Many reports are available about the exposure time of semen to glycerol, but different results were achieved. In ejaculated bull semen a shorter equilibration time has been recommended because longer exposure to glycerol was suggested to be detrimental to sperm survival. Exposure times compared were 0.5 and $18 \mathrm{~h}$ (O'Dell \& Hurst 1956; Berndtson \& Foote 1972). Contrary to these reports are results that indicate no differences in the percentage of intact acrosomes and motile spermatozoa in bovine semen samples when equilibrated for 0.5 or 2 h (Wiggin \& Almquist 1975a). Wiggin \& Almquist (1975b) also reported that equilibration times of more than $4 \mathrm{~h}$ are detrimental to semen and recommended $2 \mathrm{~h}$. In equids, no difference in the postthaw motility have been found after samples were exposed to pre-freeze equilibration times between 30 and 120 min (Jimenez 1987).

No reports are available for African buffalo semen equilibrated for different times using glycerol containing media before freezing. Since laboratories are often some hours away from the site of collection, we compared equilibration times between 2 and $9 \mathrm{~h}$ rather then shorter ones as done in some of the above-mentioned studies. Our results were similar to those in the study described by Jimenez 
1987). We also did not observe any differences between equilibration times longer than $3 \mathrm{~h}$ for any of the media used. Although we used a similar concentration of glycerol we did not observe any detrimental effect owing to exposure times exceeding $4 \mathrm{~h}$. We found equilibration times of 2 and $3 \mathrm{~h}$ to be inferior. These differences can be due either to the fact that we used epididymal sperm or to species differences.

A post-thaw semen parameter which is rarely measured, is longevity and our results show that it might be useful to compare this more often. When post-thaw motilities were compared immediately after thawing the use of Red Ovine Freezing Buffer resulted in higher total motility than AndroMed® and in a higher progressive motility than for both AndroMed $\AA$ and Triladyl ${ }^{\mathrm{TM}}$. After incubation for $2 \mathrm{~h}$ in a $37^{\circ} \mathrm{C}$ water bath the progressive motility for using Red Ovine Freezing Buffer decreased to $2 \pm$ 6 . This means that only $8 \%$ of the spermatozoa that were progressively motile immediately after thawing were still intact $2 \mathrm{~h}$ after thawing. This figure was $18 \%$ for AndroMed $\AA$ and $82 \%$ for Triladyl ${ }^{\mathrm{TM}}$. The decrease of sperm motility when ROFB and AndroMed $\AA$ were used was only significant when compared to the values before freezing, but not when compared to the ones immediately after thawing. This fact was attributed to the low number of samples, as only six buffaloes were available. The trend seemed to be that progressive motility decreased less over the $2 \mathrm{~h}$ observation period when sperm is frozen with Trilady| ${ }^{\mathrm{TM}}$.

Ordinary spermatozoa staining techniques such as eosin/nigrosin are not useful to evaluate acrosomal integrity. Electron microscopy is an accurate method for assessing the acrosomal status, but it is expensive and very laborious. Indirect immunofluorescence techniques employing monoclonal antibodies are not available for African buffaloes. Lectins are widely used to bind to glyconconjugates of the outer acrosomal membrane and are made visible by markers such as fluorescein isothiocynate (FITC). Staining spermatozoa with FITC-PNA is comparatively simple and allows the easy assessment of the acrosomal status. FITC-PNA has been used to stain spermatozoa of stallions (Rathi, Colenbrander, Bevers \& Gadella 2001), boars (Flesch, Colenbrander, Van Golde \& Gadella 1999), bulls (Garner et al. 1999), dogs (Sirivaidyapong, Bevers, Gadella \& Colenbrander 2001) and humans (Mortimer, Curtis \& Miller 1987). The percentages of intact acrosomes in our study were low in comparison to previous work, where percentages of $67-77 \%$ (Gerber et al.
2001), 80-87\% (Gerber et al. 2002) and 58-64\% (Lambrechts et al. 1999) intact acrosomes were reported. Since we used (at least when Trilady| ${ }^{\mathrm{TM}}$ was used) very similar freezing protocols it is possible that the higher percentages of intact acrosomes found by these researchers can be attributed to the techniques used to evaluate the acrosomal integrity. It appears therefore that eosin/nigrosin staining is inferior to FITC-PNA staining to selectively stain the acrosomal membrane for the evaluation of acrosomal integrity.

Since during routine inseminations many cows are not inseminated at the optimal time, it would not be surprising if longevity has a significant effect on non-return rates. Whether an increased longevity, as it was found in the present study, has an influence on the non-return rate needs to be tested.

An interesting observation of our study was that progressive motility was higher or as high immediately after thawing as it was before freezing when Trilady| ${ }^{\mathrm{TM}}$ (19\% and $19 \%$, respectively) or Red Ovine Freezing Buffer $(29 \%$ and $24 \%$, respectively) were used. It is unlikely that sperm samples can be frozen without damaging any sperm. We therefore assume that some of the spermatozoa that were not moving when evaluated before thawing, were in a quiescent stage and not immotile because of damage. It is known that spermatozoa of Bos taurus bulls (Carr \& Acott 1984) as well as of rats, guinea pigs, hamsters and humans (Turner \& Reich 1985) are kept in the epididymides in a quiescent state, even though they are fully capable of moving. The reason for this quiescence in bulls was suggested to be a pH-dependent factor present in cauda epididymal fluid (CEF), which becomes inactivated as well as diluted during addition of seminal plasma to epididymal spermatozoa upon ejaculation (Acott \& Carr 1984). The ability to immobilize spermatozoa temporarily has also been attributed to glycerolphosphocholin (GPC) and carnitin, which are both present in high concentrations in rat CEF (Turner, D'Addario \& Howards 1978). In bulls the half-time of motility initiation upon dilution is given as being 2 to 5 min (Acott \& Carr 1984). It is therefore possible that not all spermatozoa were released from their quiescent state when we first evaluated the motility. Another possibility is that Triladyl ${ }^{\mathrm{TM}}$ as well as Red Ovine Freezing Buffer contain substances that prolong the quiescent state of spermatozoa. In any case, it seems that some of the spermatozoa, which were recorded as immotile before freezing, were in fact in a quiescent state and only subsequently became motile owing to longer expo- 
sure to the semen diluent as well as dilution of CEF. Since we assume it to be an advantage to freeze epididymal spermatozoa in the quiescent state because more energy is conserved by them, it is desirable to investigate this phenomenon further.

It can be concluded from our results that equilibration times between 4 and $9 \mathrm{~h}$ do not influence postthaw semen qualities and no attention must therefore be paid to it. We further conclude that shorter equilibration times are detrimental. This knowledge is very valuable when freezing sperm of wild animal species in the field.

Furthermore, it was found that Trilady ${ }^{\mathrm{TM}}$ was superior to Red Ovine Freezing Buffer and AndroMed® when used as a freezing diluent for epididymal African buffalo sperm. Although AndroMed® is a totally defined medium, it cannot be recommended, since the results obtained in this study concerning progressive motility, longevity and acrosomal integrity of the sperm were inferior to those when Triladyl ${ }^{\mathrm{TM}}$ was used.

\section{ACKNOWLEDGEMENTS}

The authors would like to thank IMV France and Minitüb Germany for providing the buffers and extenders, respectively.

\section{REFERENCES}

ACOTT, T.S. \& CARR, D.W. 1984. Inhibition of bovine spermatozoa by caudal epididymal fluid: II. Interaction of $\mathrm{pH}$ and a quiescence factor. Biology of Reproduction, 30:926-935.

BARTELS, P., LAMBRECHTS, H., KIDSON, A. \& FRIEDMANN, Y. 1996. The potential of breeding disease-free African buffalo using assisted reproductive technology. Proceedings of a Symposium on the African Buffalo as a Game Ranch Animal, Onderstepoort, South Africa, 1996:75-78.

BENGIS, R.G., KRIEK, N.P.J., KEET, D.F., RAATH, J.P., DE VOS, V. \& HUCHZERMEYER, H.F.A.K. 1996. An outbreak of bovine tuberculosis in a free-living African buffalo (Syncerus caffer-Sparrman) population in the Kruger National Park: a preliminary report. Onderstepoort Journal of Veterinary Research, 63:15-18.

BENGIS, R.G., THOMSON, G.R. \& DE VOS, V. 1987. Foot-andmouth disease and the African buffalo: a review. Journal of the South African Veterinary Association, 58:160-162.

BERNDTSON, W.E. \& FOOTE, R.H. 1972. Bull sperm survival following freezing in ampoules, pellets and straws. Proceedings of the 7th International Congress on Animal Reproduction and Artificial Insemination, Munich, 1972:1353-1356.

CARR, D.W. \& ACOTT, T.S. 1984. Inhibition of bovine spermatozoa by caudal epididymal fluid: I. Studies of a sperm motility quiescence factor. Biology of Reproduction, 30:913-925.

CORREA, J.R. \& ZAVOS, P.M. 1995. Frozen-thawed bovine spermatozoa diluted by slow or rapid dilution method: meas- urements on occurrence of osmotic shock and sperm viability. Theriogenology, 44:963-971.

DE VOS, V. 1987. The status and distribution of the buffalo (Syncerus caffer) in South Africa. Journal of the South African Veterinary Association, 58:157.

FLESCH, F.M., COLENBRANDER, B., VAN GOLDE, L.M.G. \& GADELLA, B.M. 1999. Capacitation induces tyrosine phosphorylation of proteins in the boar sperm plasma membrane. Biochemical and Biophysical Research Communications, 262:787-792.

GARNER, D.L., THOMAS, C.A. \& GRAVANCE, C.G. 1999. The effect of glycerol on the viability, mitochondrial function and acrosomal integrity of bovine spermatozoa. Reproduction of Domestic Animals, 34:399-404.

GERBER, D. 2000. Breeding "disease free" African buffalos (Syncerus caffer). Proceedings of the Symposium on Wildlife Utilization in Southern Africa, Pretoria, 2000.

GERBER, D., IRONS, P.C., ARLOTTO, A. \& COOPER, D. 2001. Quality and freezability of epididymal semen from African buffalo (Syncerus caffer) under field conditions. Theriogenology, 55:384.

GERBER, D., IRONS, P.C., HEROLD, F.C. \& COOPER, D. 2002. Quality and freezability of epididymal semen from African buffalo (Syncerus caffer) following prolonged exposure to ambient temperatures or delayed flushing. Theriogenology, 57:582.

HARTMANN, S., LACORN, M. \& STEINHARDT, H. 1998. Natural occurrence of steroid hormones in food. Food Chemistry, 62:7-20.

HEDGER, R.S. \& CONDY, J.B. 1985. Transmission of foot-andmouth disease from African buffalo virus carriers to bovines. Veterinary Record, 117:205.

HERR, S. \& MARSHALL, C. 1981. Brucellosis in free-living African buffalo (Syncerus caffer): a serological survey. Onderstepoort Journal of Veterinary Research, 48:133-134.

HOPKINS, S.M., ARMSTRONG, D.L., HUMMEL, S.K.C. \& JUNIOR, S. 1988. Successful cryopreservation of gaur (Bos gaurus) epididymal spermatozoa. Journal of Zoo Animal Medicine, 19:195-201.

JIMENEZ, C.F. 1987. Effects of Equex STM and equilibration time on the pre-freeze and postthaw motility of equine epididymal spermatozoa. Theriogenology, 28:773-782.

KILIAN, I., LUBBE, K., BARTELS, P., FRIEDMANN, Y. \& DENNISTON, R.S. 2000. Evaluating epididymal sperm of African wild ruminants: longevity when stored at $4{ }^{\circ} \mathrm{C}$ and viability following cryopreservation. Theriogenology, 53:336.

LAMBRECHTS, H., VAN NIEKERK, F.E., COETZER, W.A., CLOETE, S.W.P. \& VAN DER HORST, G. 1999. The effect of cryopreservation on the survivability, viability and motility of epididymal African buffalo (Syncerus caffer) spermatozoa. Theriogenology, 52:1241-1249.

MORTIMER, D., CURTIS, E.F. \& MILLER, R.G. 1987. Specific labelling by peanut agglutinin of the outer acrosomal mambrane of the human spermatozoa. Journal of Reproduction and Fertility, 81:127-135.

MÜLLER-SCHLÖSSER, F., AIRES, V., HINSCH, E. \& HINSCH, K.-D. 2001. Evaluation of the quality of a new generation of egg yolk-free semen diluters for cryopreservation of bovine semen. 34. Jahrestagung Physiologie und Pathologie der Fortpflanzung, Giessen, 2001:54.

O'DELL, W.T. \& HURST, V. 1956. The effect of glycerol equilibration time on the freezing of bovine spermatozoa in egg yolk sodium citrate and skim milk semen extenders. Journal of Dairy Science, 39:1156-1160. 
POTGIETER, F.T., STOLTSZ, W.H., BLOUIN, E.F. \& ROOS, J.A. 1988. Corridor disease in South Africa: a review of the current status. Journal of the South African Veterinary Association, 59:155-160.

RATHI, R., COLENBRANDER, B., BEVERS, M.M. \& GADELLA, B.M. 2001. Evaluation of in vitro capacitation of stallion spermatozoa. Biology of Reproduction, 65:462-470.

SIRIVAIDYAPONG, S., BEVERS, M.M., GADELLA, B.M. \& COLENBRANDER, B. 2001. Induction of the acrosome reaction in dog sperm cells is dependant on epididymal maturation: The generation of a functional progesterone receptor is involved. Molecular Reproduction and Development, 58:451459.

STEWART, D.L. \& O'HAGAN, C. 1972. The prediction of the fertility of bull semen from laboratory tests. Seventh Internation- al Congress on Animal Reproduction and Artificial Insemination, Munich, 1972:1279-1283.

TURNER, T.T., D'ADDARIO, D. \& HOWARDS, S.S. 1978. Further observations on the initiation of sperm motility. Biology of Reproduction, 19:1095-1101.

TURNER, T.T. \& REICH, G.W. 1985. Cauda epididymal sperm motility: a comparison among five species. Biology of Reproduction, 32:120-128.

WIGGIN, H.B. \& ALMQUIST, J.O. 1975a. Effect of glycerol equilibration time and thawing rate upon acrosomal maintenance and motility of bull spermatozoa frozen in plastic straws. Journal of Animal Science, 40:302-305.

WIGGIN, H.B. \& ALMQUIST, J.O. 1975b. Combinations of glycerol percent, glycerol equilibration time, and thawing rate upon freezability of bull spermatozoa in plastic straws. Journal of Dairy Science, 58:416-419. 